\title{
STRUCTURAL EQUATIONS MODELING OF THE RELATIONSHIP BETWEEN HUMAN RESOURCE STRATEGIES AND TALENT MANAGEMENT WITH THE ROLE OF EDUCATING WORKERS IN GOVERNMENTAL ORGANIZATIONS OF KERMAN PROVINCE
}

\author{
MODELO DE ECUACIONES ESTRUCTURALES DE LA RELACIÓN ENTRE LAS ESTRATEGIAS DE \\ RECURSOS HUMANOS Y LA GESTIÓN DEL TALENTO CON EL PAPEL DE EDUCAR A LOS \\ TRABAJADORES EN LAS ORGANIZACIONES GUBERNAMENTALES DE LA PROVINCIA DE \\ KERMAN
}

\section{MODELAGEM DE EQUAÇÕES ESTRUTURAIS DA RELAÇÃO ENTRE ESTRATÉGIAS DE RECURSOS HUMANOS E GESTÃO DE TALENTOS COM O PAPEL DE EDUCAR TRABALHADORES EM ORGANIZAÇÕES GOVERNAMENTAIS DA PROVÍNCIA DE KERMAN}

\author{
Sedigheh Hasani Ahmadiyeh ${ }^{1}$ \\ Alireza Manzari Tavakoli 2 \\ Sanjar Salajegheh ${ }^{3}$ \\ Ayob Sheykhi ${ }^{4}$ \\ Masoud Pourkiani ${ }^{5}$
}

\begin{abstract}
This study aimed to model the structural equations of the relationship between HR strategies and talent management with respect to the educating workers. The current research is applied and developmental in terms of purpose and with regard to the research method it is a descriptive and correlational one. The statistical population of this study included all employees of government agencies in Kerman province in 2019 ( $n=8675)$, and the sample size was 367 using Cochran formula, which were selected by stratified random sampling. Data collection instrument consisted of three researcher-made questionnaires including 50-item queastionaire of HR strategies with validity of 0.82 and reliability of $0.87,50$-item questionaire of talent management with validity of 0.77 and reliability of 0.79 and 98 questionnaires of knowledge worker employees with validity of 0.84 and reliability of 0.74 . Structural equation modeling using amos 22 software was used for data analysis. The results revealed that the relationship between human resource strategies to educate the
\end{abstract}

\footnotetext{
${ }^{1}$ Islamic Azad University, Kerman, Iran.

${ }^{2}$ Islamic Azad University, Kerman, Iran.

${ }^{3}$ Islamic Azad University, Kerman, Iran.

${ }^{4}$ Shahid Bahonar University, kerman, Iran.

${ }^{5}$ Islamic Azad University, Kerman, Iran.
} 
foals of this study to the workers in Kerman province government agencies was well-fitted. Strategies Human resources, which involves commitment, free agent, paternalistic, secondary strategies, can have a significant relationship with talent management, including the components of hire, evaluate, develop and maintain, and knowledge workers have mediating role with knowledge and technical reasoning, individual skills and attitudes, professional skills and attitudes, interpersonal skills and attitudes, and system, product, and process development skills in line with HR strategies and talent management, and free agent strategy is the best and most effective HR strategy that affects talent management.

Keywords: Educating Human Resource Strategies, Talent Management, Knowledge Workers.

Resumo: Este estudio tuvo como objetivo modelar las ecuaciones estructurales de la relación entre las estrategias de recursos humanos y la gestión del talento con respecto a los trabajadores en educación. La investigación actual se aplica y desarrolla en términos de propósito y con respecto al método de investigación es descriptivo y correlacional. La población estadística de este estudio incluyó a todos los empleados de agencias gubernamentales en la provincia de Kerman en 2019 ( $n=8675)$, y el tamaño de la muestra fue 367 utilizando la fórmula de Cochran, que se seleccionaron mediante muestreo aleatorio estratificado. El instrumento de recopilación de datos consistió en tres cuestionarios realizados por investigadores que incluyeron cuestionario de estrategias de RRHH de 50 ítems con una validez de 0.82 y confiabilidad de 0.87 , cuestionario de 50 ítems de gestión del talento con una validez de 0.77 y confiabilidad de 0.79 y 98 cuestionarios de empleados con trabajadores del conocimiento con validez de 0.84 y confiabilidad de 0.74 . Se utilizó el modelado de ecuaciones estructurales utilizando el software amos 22 para el análisis de datos. Los resultados revelaron que la relación entre las estrategias de recursos humanos para educar a los potros de este estudio a los trabajadores de las agencias gubernamentales de la provincia de Kerman era adecuada. Estrategias Los recursos humanos, que implican compromiso, agente libre, estrategias paternalistas, secundarias, pueden tener una relación significativa con la gestión del talento, incluidos los componentes de contratación, evaluación, desarrollo y mantenimiento, y los trabajadores del conocimiento tienen un papel mediador con el conocimiento y el razonamiento técnico, individual habilidades y actitudes, habilidades y actitudes profesionales, habilidades y actitudes interpersonales, y habilidades de desarrollo de sistemas, productos y procesos en línea con las estrategias de recursos humanos y la gestión del talento, y la estrategia de agente libre es la mejor y más efectiva estrategia de recursos humanos que afecta la gestión del talento.

Palabras clave: Educación de estrategias de recursos humanos, Gestión del talento, Trabajadores del conocimiento.

Resumo: Este estudo teve como objetivo modelar as equações estruturais da relação entre estratégias de $\mathrm{RH}$ e gestão de talentos em relação à formação de trabalhadores. A pesquisa atual é aplicada e de desenvolvimento em termos de finalidade e, em relação ao método de pesquisa, é descritiva e correlacional. A população estatística deste estudo incluiu todos os funcionários de agências governamentais na província de Kerman em 2019 ( $n=8675$ ), e o tamanho da amostra foi de 367 usando a fórmula de Cochran, que foram selecionados por amostragem aleatória estratificada. $O$ instrumento de coleta de dados consistiu em três questionários elaborados pelo pesquisador, incluindo questionário de 50 itens sobre estratégias de RH com validade de 0,82 e confiabilidade de 0,87 , questionário de 50 itens de gestão de talentos com validade de 0,77 e confiabilidade de 0,79 e confiabilidade de 0,79 e 98 questionários de funcionários validade de 0,84 e confiabilidade de 0,74 . Modelagem de equações estruturais utilizando o software amos 22 foi utilizada para análise dos dados. Os resultados revelaram que a relação entre estratégias de recursos humanos para educar os potros deste estudo para os trabalhadores das agências governamentais da província de Kerman estava bem ajustada. Estratégias Os recursos humanos, que envolvem comprometimento, agente livre, estratégias paternalistas e secundárias, podem ter um relacionamento significativo com a gestão de talentos, incluindo os componentes de contratação, avaliação, desenvolvimento e manutenção, e os trabalhadores do conhecimento têm papel mediador do conhecimento e do raciocínio técnico, individual habilidades e 
atitudes, habilidades e atitudes profissionais, habilidades e atitudes interpessoais e habilidades de desenvolvimento de sistemas, produtos e processos alinhadas às estratégias de $\mathrm{RH}$ e gerenciamento de talentos, e a estratégia de agente livre é a melhor e mais eficaz estratégia de RH que afeta o gerenciamento de talentos.

Palavras-chave: Educando Estratégias de Recursos Humanos, Gestão de Talentos, Trabalhadores do Conhecimento.

\section{INTRODUCTION}

Human resource performance is influenced by important variables in the organization, among which one can mention talent management. Given that "human capital" is recognized as an important and competitive asset of organization, and human resource managers, considering the importance of this capital, are able to create competitive advantage for the future of the organization (Tonkejnejad M. \& Davari A., 2009). Human resource managers improve organizational, group, and individual performance through educating employees, creaing dynamic organization and providing growth and development opportunities for employees (Ebrahimi \& Fathi, 2016). (Lewis \& Heckman, 2006) define talent management as a set of human resources tasks such as hiring, selection, development, and career and succession management. Accordingly, they argue that talent management may be another interpretation of the term human resource management. Following a thorough and comprehensive review of the literature on talent management, they indicated that talent management is a systematic way to perform HR tasks with a broader and more accurate view (Hughes \& Rog, 2018).

(Miller, 2006) believes that a HR strategy should be aligned and consistent with the organization's strategies. So that by providing harmony between the organization's strategies and human resources policies, synergies in the activities of the organization will increase (Chadwick, 2005).

Many studies have been done in line with the strategy formulation and the implementation of HR strategy. In the strategy formulation field, more comprehensive activities have been theoretically done than the implementation and execution of the HR strategy, because it was thought to be the root of all the problems in formulating HR strategy. Though, recent studies show that in many companies and organizations there is no problem in formulating the strategy and its content and in spite of that, the strategies have failed. For instance, (Armstrong, 2015) state that in all of the organizations they studied "in all cases (without exception) everyone knew what to do, but problems and issues actually occurred that made achieving the desired changes difficult", and 
that is why (Millar \& Stevens, 2012) states that "organizations fail to implement more than 70 percent of their new HR strategies." According to these issues and problems, the scientific focus on strategic management has shifted from formulating a human resources strategy to conducting it and extensive research has begun in this field.

HR strategies strive to provide sustainable competitive advantage in each of the organizational units with regard to their HR strengths, weaknesses, opportunities, and threats, create sustainable competitive advantages, explains the vital and key tasks of managers in the field of human resources, identifies key and managerial tasks, creates a consistent and integrated model or set of decisions, defines the economic and non-economic values of the human resources it wants to create for stakeholders, and states the goals, intentions and orientations of the institution (Shams Zare et al, 2017).

Today's knowledge-based organizations are considered as the key resource for sustained competitive advantage. The importance of employing appropriate HRM approaches to ensure the success of an organization in such a competitive environment is indisputable. At the same time, given the dynamics and constant changes in the environment, the HRM process should not be considered a static phenomenon. Considering organizations as living, dynamic and learner phenomena necessitates the use of a so-called strategic approach to human resource management (Ebrahimi \& Fathi, 2016).

When manpower is knowledge-based and unique, it provides strategic benefits to the organization, of course, the development and deployment of this human capital lead to administrative and bureaucratic costs. Organizations incentive to invest and develop this type of knowledge base human resources, maximize the potential of organizational creativity, and create distinctive features within the organization. Therefore, in order to achieve such a goal, organizations must deploy commitment-based HR systems. Though the knowledge-base human resource is necessarily value-creating, it is unique and exclusive to the organization itself (Soltani, 2013).

Presently, in many organizations, scientific competency-based human resource management techniques are used that can create a appropriate connection between the work and capabilities of individuals. In fact, scientific competencies can be a common language for different functions of human resources. If the human resources systems of the organizations are examined, it becomes clear that most of the time there is no necessary communication between its various subsystems such as training, performance evaluation, recruitment, etc. and this leads to inefficiencies of the human resources systems. In other words, the strong overlap between different 
human resource subsystems to enhance their interoperability is one of the issues that is of less concern today in organizations. One of the best and most appropriate approaches to achieving this is the application of the scientific competencies approach in human resource management (Karami \& Salehi, 2009).

On the other hand, apart from the organizational approach, the existence of knowledge workers is a necessity for the growth and development of each individual in different areas of life, education and work. (Li et al, 2009) admit that the existence of knowledge wokers is essential to learning, working and living tasks. Schmidt and Henninger also believe that the ability of personal knowledge management practices has become a key competence in today's society. While the focus of individual knowledge management is on person, its purpose is to enable individuals to perform effectively in the formal structure of the organization and working groups. The central emphasis of knowledge is the focus on individual research and effort, the pursuit of finding, communicating, learning and exploring (Verma, 2009).

Losing good staff can impose enormous costs on the organization; even if the organization can afford to pay the costs of identifying basic human resources, it may not be possible to attract good staff for a long time. Today, in most countries, while occupation is still an unsolved problem, as a result, the emergence of new technologies, the opening up of new markets, the increasing demand for the supply of power are mainly considered. It is therefore imperative that organizations identify and maintain these key assets. In the competitive filed, the most successful organizations are those that can manage human capital in effective and efficient ways. This requires identifying the challenges and dangers of maintaining basic human knowledge and addressing those risks. (Bamberger \& Meshoulam, 2014).

On the other hand, the low performance of government organizationas and agencies clearly indicates that knowledgeable and skilled people are not in their positions and in the case of selfexpression they would be repressed. Among the reasons for this issue, one may mention the increasing influence of relationships in employing individuals rather than the rules. Other reasons include lack of allocating anought budget and funding for talented individuals, failure to identify talented individuals, lack of a rich program to maintain or nurture them, lack of attention to the value and performance of talented staff, and fear of senior executives fearing a job loss These individuals themselves and the lack of compliance with managerial orders have also led to the disregard of government agencies for talent recruitment and retention, thereby reducing the performance of the organization and leaving out and losing talent. Human resources are the most 
important competitive advantage and organizational capital and therefore emphasize the valuable role of talent in the organization and their optimal management is considered very important and sensitive. With the advent of words such as talent management, we are witnessing a paradigm shift from traditional HRM to a new HRM that involves attention to organizational elites. At the same time, talent retention is one of the first steps in talent management.

Consequently, the present study aimed to explain the relationship between human resource strategi-es and talent management with the mediating role of knowledge worker in Kerman province government agencies and presenting a desirable model. Given the mediating role of knowledge workers, how can talent management in government agencies be affected in this province?

\section{Theoretical Framework}

In the current study, talent management is considered as the criterion variable, a variable that its changes would be interpreted and explained by HR strategies as predictive and mediating variables of knowledge workers.

Talent management assures organizations to have the right people, the right skills, and the right position. Talent management has a cycle that consists of three main areas: identifying and attracting talent, retaining talent, and developing talent. Today's organizations no longer seek to recruit, but to attract talent, which is referred to as talents battle or a war for talent (Tajeddin \& Malaali Tafti, 2011).

As methodical steps are taken to attract customers, to attract organizational talent, one must also act systematically. The best strategy to succeed in competition for talent is not to recruit all the talented people but to recruit the most appropriate ones. In other words, it is about discovering, attracting, managing and interacting with those who can be motivated, committed and efficient in the organization work environment (Michaels et al, 2010).

One of the most popular models in talent management is the 4-factor model of (Bamberger \& Philips, 1991). This model includes the following factors:

1. Recruitment: One of the most important processes in talent management is attracting talented people. One of the difficulties in organizational systems is selecting and attracting the right people based on proper indicators. Google, for instance, select the right person within a 187-hour period. Creating an organizational brand and introducing the 
unique characteristics of the organization to the target audience is very important in line with attracting talented people (Roper \& Phillips, 2009).

2. Hiring: The use of objective methods of performance measurement such as psychological assessments, behavioral interviews, personality assessments, and job knowledge tests to select and adapt a person to the job has become more common today (Roper \& Phillips, 2009).

3. Development and Improvement: Due to the unique characteristics of talented people, development and improvement strategies should also be very specific. The most important role in the development of talent is played by the operational managers (direct managers). These are the managers who need to understand what makes each employee stronger. Another solution is to encourage employees to take responsibility for their personal improvement. For example, employees can be asked to identify their improvement needs. This factor (i.e. asking and individual about his or her development) also reveals latent talent (Roper \& Phillips, 2009).

4. Employee Retention: Employee retention is closely linked to the organisation's performance management system. It is very important to keep in mind the challenges and expectations of the younger generation. Talents push the organization to continually improve their capabilities and capabilities. In this respect, formulating a kind of meritocratic approach is one of the main approaches (Roper \& Phillips, 2009).

By integrating employee control and labor market-based models, (Bamberger \& Mesoulan, 2005) have introduced a two-dimensional model as an integrated model based on which the HRM decision-making model has two main questions, as a strategic reference point. The process of formulating this model is based on a (natural) attitude, but some rational attitude tools are used. Strategic reference points as an intermediary connect political power desires in the organization with a scientific approach to human resources strategy. The integrated model of (Bamberger \& Mesoulan, 2005) incorporates two dimensions (how to control and market power), ultimately resulting in the extraction of (a) a commitment strategy; (b) a free-agent strategy; (c) a paternalistic strategy; and (d) a secondary strategy. Strategic reference points are determined using job, employee exposure, and human resource subsystem characteristics.

With regard to the theory of strategic reference points and the theory of (Bamberger \& Feigenbaum , 1996), a third hybrid model was developed as a solution in the formulation of human 
resource strategy by (Schmidt \& Henninger, 2008). These two scholars by combining diverse perspectives on human resource strategy formulation, propose a unified approach that uses two dimensions of "resource supply (build or buy)" and "controling process or outcome" in determining strategic reference points. The term "sourcing" means the degree to which human resource strategies focus on providing the necessary skills or competencies within or the free market. The second dimension of 'control' is the degree or extent to which HR strategy focuses on the observation of employee behavior, which is the control of outcomes or process control (Bamberger \& Mesoulan, 2005), with the combination of two dimensions, four types of human resources strategys are obtained as follows:

Paternalistic strategy

Free-agent strategy

Commitment strategy

Secondary strategy

This strategy is suitable for simple, repetitive and standardized jobs that have sufficient labor force available outside the company market and there is no need to recruit and retain them. In other words, in the case of unnecessary or unsatisfactory work of workers and employees, an organization can easily stop cooperation, and if needed, it can hire new staff with the least training and cost in the same occupations (Ready \& Conger, 2017).

\section{Paternalistic strategy}

This strategy is also applicable to simple, repetitive, and standardized jobs, except that company management tends to retain and enhance existing employees and align them with the corporate culture. Consequently, in case of empty positions na orginaziation tries to fill with the promotion of staff (McCauley \& Wakefield, 2016).

\section{Free-agent strategy}

This strategy is suitable for those complex and specialized jobs that constant and formal recruitment of relevant experts for the company requires a high cost, as the company needs these types of jobs in short and temporary periods. So, these experts are usually are invited to collaborate with high costs, solely for consulting or doing a part of a plan, and once the project is completed, 
they will return to the labour market to provide similar services. Of course, some organizations (especially virtual organizations). The constant need to have experts is met using the temporary or unnecessary services of these experts. Because the management of these organizations has been able to fully control the means of evaluating the specific knowledge of the organization and its promotion exercise (Bamberger \& Mesoulan, 2005).

\section{Commitment strategy}

This strategy is also applicable to complex and specialized businesses, but with the difference that the active specialists in these jobs are constantly needed by the company, since they, in many cases, are perfesional in specialized network of production and knowledge, it is not easy to replace them. Therefore, it is necessary to have an effective approach to the job market within the organization, which is to develop and train company experts and strengthen their commitment and loyalty to the organization, in a way that will provide them with a secure and dynamic job market. Work outside the organization to ignore. In strategic reference points theory, a three-dimensional matrix is used to determine the reference points, which includes the internal conditions of the organization, external conditions of the organization, and time (Seetherman et al, 2012). The strategic reference points based theory is principally based on the intelligent planning approach. But (Bamberger \& Feigenbaum, 1996) use several theoretical perspectives such as motivation theory, strategic goal theory, and dependency theory to point sources that considering different perspectives a wide range of points of view can be mentioned to create models (Bamberger \& Mesoulan, 2005).

In the model presented by Bemberger and Mesoulan, human resource management is considerd from two aspects: human resource goals or objectives and ways to achieve goals. Goals that human resources management wantys to realize them are as follows: the scope of employes' roles, the workforce (skills) integration, the expected competence, the expected commitment, the quick resources flexibility and adaptation. In this model, the three tools can be found for achieving human resource management goals: "Subsystem", "Performance and Remuneration Assessment Subsystem" and "Employee Relations"

(Motahari Nejad et al, 2012) have presented five characteristics for scientific competence and capability as follows: 
Knowledge and technical reasoning: Knowledge and technical reasoning measn having knowledge about basic sciences, basic and advanced concepts and principles, ability to reason and solve problems, ability to test and discover knowledge and systemic thinking.

Individual Skills and Attitudes: Individual skills and attitudes mean the ability to take risks, flexibility, creative and critical thinking, and to be aware of personal strengths and weaknesses and the ability to manage themselves.

Professional Skills and Attitudes: Ethical and scientific skills and attitudes means understanding professional and ethical responsibility and behavior, the ability to plan for a career path, and remain as an expert, innovation and entrepreneurship skills means employing effective new ideas and the ability to participate in sustainable development

Interpersonal Skills and Attitudes: Interpersonal skills and attitudes include management and leadership skills, the ability to work in multidisciplinary teams, the ability to communicate effectively with others (verbal, writing, graphic and electronic) and the ability to communicate in foreign languages.

System, Product, and Process Development Skills: A system, product, and process development skill is the abalitiy of understanding society and the global environment and its impact on accounting, understanding organizations and companies, and working effectively with them, imagining a system, product, or process in mind, needs and conditions, the design of a system, product or process to meet the needs, implementation of a design into a system, product or process and the ability to exploit a system, product, or process to deliver the desired value.

\section{The Conceptual Model}

Criterion variable

\begin{tabular}{|c|}
\hline Talent management \\
\hline Recruitment \\
Continuous evaluation \\
Staff retention \\
Development and \\
improvement \\
\end{tabular}

Mediator variable

Predictor variable

Knowldege workers
Knowledge and technical
reasoning
Individual skills and attitude
Professional skills and
attitudes
Interpersonal skills and
attitudes
System, product and process
development skills

\author{
Human resource \\ stratefies \\ Paternalistic strategy \\ Free-agent strategy \\ Commitment \\ strategy \\ Secondary strategy
}




\section{METHOD}

The current resravch is applied and developmental in terms of objectibe and in terms of research $\mathrm{m}$,ethodology it is a correlational research. The data gathering $\mathrm{p}$ [rocedure was field method. The statistical population of this research includes all employees of government agencies and organizations in Kerman Province in 2019 ( $n=8675)$ and the sample size was 367 by means of Cochran formula that they were selected via starifies random sampling method. The human resource strategy questionnaire with 50 items was based on a 5-point Likert scale (from totally disaggre to totally agree). This questionnaire asses the human resources strategies in four dimensions that are paternalistic, free-agent, commitment, secondary strategies. The basic knowledge workers questionnaire consists of 98 questions based on a 5-point Likert scale from strongly disagree to strongly agree. This questionnaire assess the knowlrdge workers in 5 dimensions including technical knowledge and reasoning, individual skills and attitudes, professional skills and attitudes, interpersonal skills and attitudes, and system, product, and process development skills. Face validity of HR strategies and talent management and knowledge workers questionnaires were $0.82,0.77$ and 0.84 , respectively, and their construct validity based on exploratory factor analysis was 0.54, 0.49, and 0.55, respectively. The reliability of the questionnaires by Cronbach's alpha coefficient was $0.87,0.79$ and 0.74 , respectively. Structural equation modeling using amos22 software was used for data analysis.

\section{FINDINGS}

\section{Evaluation of Proposed Pattern Using Structural Equation Modeling}

Structural equation modeling (SEM) was used to evaluate the proposed model. Before examining the structural coefficients, pattern fit was examined. The fitting of the initial model based on the fit indices used in this study is reported in the first row (developed modeled) of (Table 1). Which shows that some of the initial model fit indices indicated that the proposed model needs reforms and improvements, for this end in the next step considering the correction indices (MI) in the output of Amos22, the covariance paths of the research variables dimensions (Figure 1) were added to the model. After making these changes another analysis was performed on the data, the results of its fitness indices are presented in the second row of (Table 1). As the (Table 1) shows, the 
first model is not well fitted. In the later stages, by adding the proposed MI paths, the improved pattern and the final pattern fit indices are accepted.

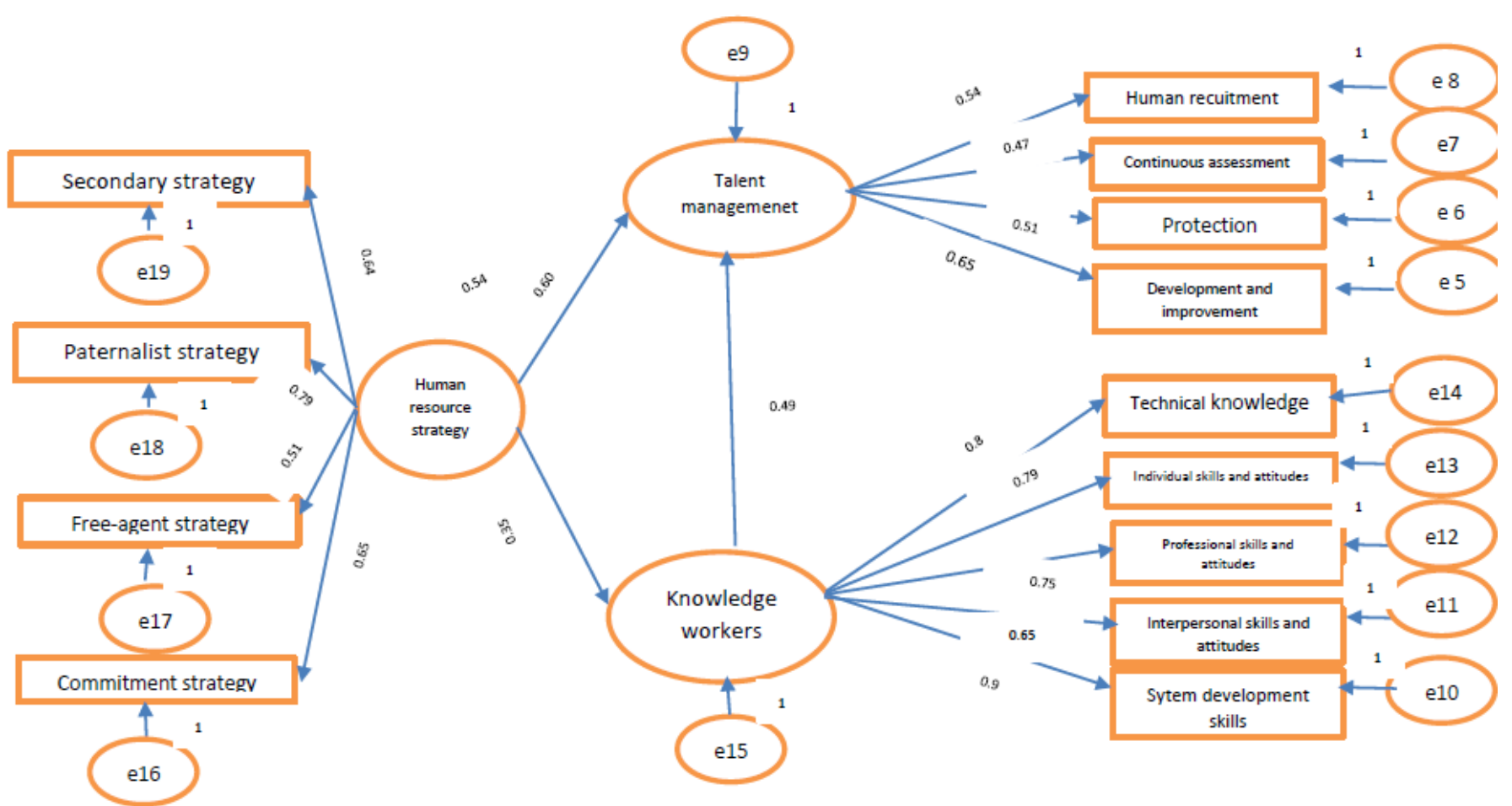

Figure 1- Structural equation model for investigating the mediating role of knowledge workers with regard to the relationship between human resource strategies and talent management (standardized coefficients)

Table 1- Model's fitness indices

\begin{tabular}{ccc}
\hline Index & Satisfactory statistic & Reported value \\
\hline RMSEA $^{6}$ & $\leq 0 / 08$ & 0.063 \\
CMIN/df & Less than 3 & 2.223 \\
GFI & $\geq 0 / 90$ & 0.956 \\
AGFI & $\geq 0 / 90$ & 0.920 \\
CFI & $\geq 0 / 90$ & 0.975 \\
IFI & $\geq 0 / 90$ & 0.975 \\
TLI & $\geq 0 / 90$ & 0.965 \\
$\mathrm{NFI}$ & $\geq 0 / 90$ & 0.956 \\
\hline
\end{tabular}

\footnotetext{
${ }^{6}$ root mean square error of approximation (RMSEA)
} 
For the fit index CMNI/Df, values smaller than 5 are appropriate and as close to zero as possible indicate good fit of the pattern. For the GFI, AGFI, IFI, CFI, and TLI indices, the values close to 0.90 and above are considered as appropriate goodeness of fit, indicating that the model is good. In relation to the RMSEA index, values close to 0.05 or less indicate a good fit to the model and a value of 0.08 or less indicates a logic error approximation; a value above 0.10 indicates the need to reject the model (Tahmasebi et al, 2013). Therefore, considering the values of the fit indices of the final model (developed model) and the acceptable value boundary stated above, it can be said that the model presented in this study is acceptable. The path coefficients between the final pattern variables and their significance level are reported in (Table 2). The path coefficients and t-test statistic's values of the model show that the mentioned variables explain the relationship between HR strategies and talent management with the mediating role of knowledge workers in Kerman province government agencies very well.

Using the general fit indices, one can answer the question whether or not, regardless of the specific values reported for the parameters, is the developed model generally supported by the empirical data collected? If the answer is yes, the model is acceptable. To interpret the values in the table above, it should be state that:

- The presence of non-significant chi-square (CMIN) equal to 117.819 and significance level $(P=0.001)$ show favorable results, but the role of degree of freedom (Df) is also important. In addition, given the degree of freedom (Df) of the fitted model (53) is far from zero and approaches the degree of independence of the model independence (78), the model should be considered appropirate.

- The number of free parameters for the developed model (NPAR), which is 35 , shows that the researcher in the model development did not easily spend the degrees of freedom and this state is acceptable.

- As for the relative indices, it can be mentioned that the relative chi-square value (CMIN / DF) is 2.223 , indicating an appropriate situation for the model. Also, the value of 0.063 for the root mean square error $\left(\mathrm{RMSEA}^{7}\right)$ index for the developed factor model indicates that the model is acceptable. 
- In the table above, the Tucker-Lewis fit index (TLI) is 0.965 and the comparative fit index (CFI) is 0.975 , and since their values are above 0.90 , so, the developed model is considered acceptable on the basis of these indices.

- In the table above, the goodness of fit index (GFI) is 0.965 and the incremental fit index (IFI) is 0.975 , both of which show acceptable values. The values of the general fit indices shown in the table above show that the measurement model of this study is quite acceptable.

To investigate the mediating role of knowledge workers in the relationship between human resource strategy factors (secondary strategy, paternalist strategy, free-agent strategy and commitment strategy) and talent management, structural equation modelling was utilized. Model`s fitness indices have been presented in (Table 3). Overall, considering the presented indices, the model has an appropriate fitness. The reported results of (Table 3) indicate the mediating role of knowledge workers in relation between human resource strategy factors and talent management. Since in all tests, the value of t-test was more than 1.96 and p-value was less than 0.05 . Thus, study`s hypotheses were accepted (Figure 2).

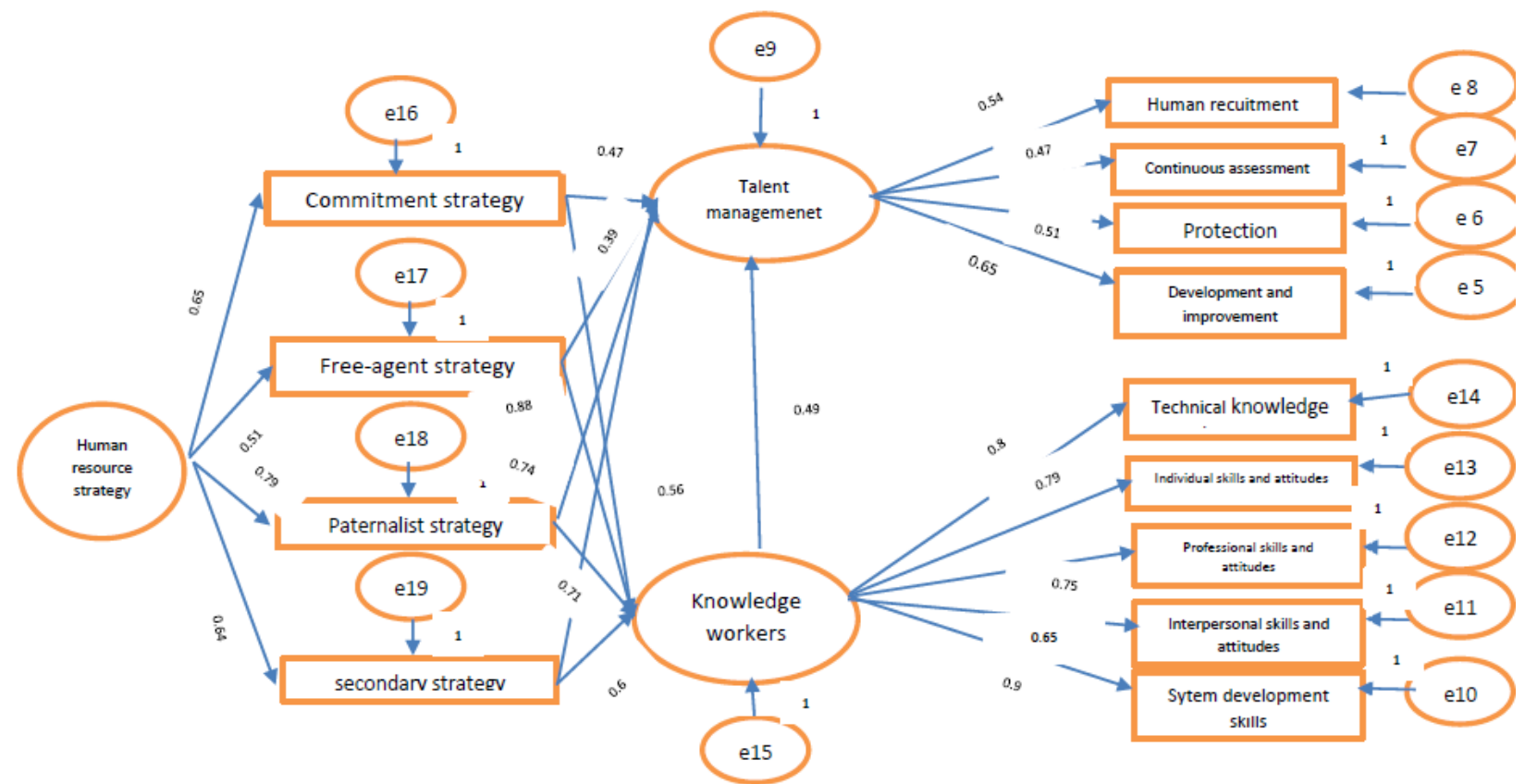

Figure 2- structural equation model for investigating the mediating role of knowledge workers in the relationship between human resource strategy factors and talent management (standardized coefficients) 
Table 2- Model`s fitness indices

\begin{tabular}{ccc}
\hline Index & Satisfactory statistic & Reported value \\
\hline RMSEA & $\leq 0 / 08$ & 0.074 \\
CMIN/df & Less than 3 & 2.039 \\
GFI & $\geq 0 / 90$ & 0.956 \\
AGFI & $\geq 0 / 90$ & 0.912 \\
CFI & $\geq 0 / 90$ & 0.984 \\
IFI & $\geq 0 / 90$ & 0.916 \\
TLI & $\geq 0 / 90$ & 0.980 \\
NFI & $\geq 0 / 90$ & 0.920 \\
\hline
\end{tabular}

- In this table, the relative chi-2 (CMIN/DF) equals to 2.039 showing the acceptable circumstance of the model. Moreover, the value of 0.074 for RMSEA of agent factor states the acceptability of the model.

- In the aforesaid table, TLI index equals to 0.980 and CFI equals to 0.984 . since their values are more than 0.90 , according to these indices, the intended model is accepted.

- In the above table, GFI value equals to 0.965 and IFI value equals to 0.916 , both showing acceptable values. Overall fitness values of indices, which have bee

- $\mathrm{n}$ reported in above table, indicate the appropriateness of the above measurement model.

Table 3- Path-coefficient and its significance and testing the research hypothesis

\begin{tabular}{lccccc}
\hline $\begin{array}{c}\text { Investigated } \\
\text { relationship }\end{array}$ & $\begin{array}{c}\text { Standard } \\
\text { coefficient }\end{array}$ & t-value & p-value & result & $\begin{array}{c}\text { Kind of } \\
\text { relationship }\end{array}$ \\
\hline $\begin{array}{l}\text { Secondary strategy } \\
\text { knowledge workers }\end{array}$ & $\begin{array}{c}0.74 \text { and } \\
0.49\end{array}$ & 8.179 & 0.000 & $\begin{array}{c}\text { Hypothesis } \\
\text { confirmed }\end{array}$ & Direct \\
$\underset{\text { talent management }}{\text { Paterlaist strategy }}$ & $\begin{array}{c}0.38 \text { and } \\
0.49\end{array}$ & 7.957 & 0.000 & $\begin{array}{c}\text { Hypothesis } \\
\text { confirmed }\end{array}$ & Direct \\
$\begin{array}{l}\text { knowledge workers3 } \\
\longrightarrow\end{array}$ & & & & & \\
\hline
\end{tabular}


talent management

$\begin{array}{lccccc}\begin{array}{l}\text { Free-agent strategy } \\ \text { knowledge workers }\end{array} & \begin{array}{c}0.71 \text { and } \\ 0.49\end{array} & 9.844 & 0.000 & \begin{array}{c}\text { Hypothesis } \\ \text { confirmed }\end{array} & \text { Direct } \\ \longrightarrow & & & & \\ \text { talent management } & & & & \\ \text { Commitment strategy } & \begin{array}{c}0.60 \text { and } \\ 0.49\end{array} & 7.720 & 0.000 & \begin{array}{c}\text { Hypothesis } \\ \text { confirmed }\end{array} & \text { Direct } \\ & & & & \\ \text { knowledge workers } & & & & \\ \text { talent management } & & & & \end{array}$

The results of the model show that the regression coefficients of efectiveness of HR strategies on secondary, paternalistyic, free agent and commitement strategies are $0.72,0.73,0.88$ and 0.71 , respectively, since the significance level is less than $0.05(\alpha=0.05)$ it can therefore be said that the secondary, paternalistic, free agant, and commitement strategies are the explicit external variables that constitute the external variables of the HR strategies.

According to the results shown in (Table 2), the regression coefficient of talent management effectiveness of staff retention, development, improvement, and recruitment is $0.89,0.8,0.64$, and 0.95 , respectively. Since the level of significance is less than $0.05(\alpha=0.05)$, therefore, it can be said that employee retention, development, refinement, and recruitment are the obvious internal variables that constitute the current internal variables of talent management.

According to the results, regression coefficients of knowledge base employees' effectiveness of system, product and process development skills, interpersonal skills and attitudes, professional skills and attitudes, skills and attitudes, and technical knowledge and reasoning are $0.71,0.65,0.65$, 0.81 , and 0.64 , respectively and since the significance level is less than $0.05(\alpha=0.05)$, it can be concluded that defensive, reactive, analytical futuristic system, product and process development skills, interpersonal skills and attitudes, professional skills and attitudes, individual skills and attitudes, and technical reasoning and the apparent internal variables constitute the current internal organization strategy variable.

The results of the model test show that the regression coefficient between HR and talent management strategies is equal to 0.1 and since $P$ is smaller than the significance level $\alpha=0.05$, so at this level, the hypothesis $\mathrm{HO}$ is rejected. As a result, it can be indicated thaty there is a positive and significant relationship between human resource strategies and talent management in Kerman 
province government agencies and for one unit increase in HR strategies, talent management will be equal to 0.1 units of standard deviation.

The results of the model test show that the regression coefficient between HR strategies and knowledge base staff is 0.69 and since $P$ - is smaller than the significance level $\alpha=0.05$, at this level $\mathrm{HO}$ is rejected. Therefore, it can be concluded that there is a positive and significant relationship between HR strategies and knowledge workers in Kerman state agencies, and for a unit increase in HR strategies, the knowledge workers will also increase up to 0.69 units of standard deviation.

The results of the model test show that the regression coefficient between basic knowledge and talent management is equal to 0.58 . Since $P$ is less than the significance level $\alpha=0.05$, so at this level $\mathrm{HO}$ is rejected and as a result, it can be said that there is a positive and significant relationship between knowledge workers and talent management in Kerman province state agencies, and for one unit increase in knowledge base personnel, talent management will increase by 0.58 unit of SD.

\section{DISCUSSION}

Based on the results of the research, model of the relationship between HR strategies and talent management with the mediating role of knowledge workers in Kerman province government agencies has been appropriately fitted. So that, human resource strategies, which comprise secondary, paternalistic, free agant, and committment strategies, can have a significant relationship with talent management components including hiring, evaluation, development and retention, and knowledge workers with the components of technical knowledge and reasoning components, individual skills and attitudes, professional skills and attitudes, interpersonal skills and attitudes, and system, product and process development skills has mediating role in line with the relationship between human resource strategies and talent management. According to the results, contracting strategy is the most effective HR strategy that affects talent management. Consequently, HR contracting strategies have a decisive role in managing employees' talent in public organizations. In line with these results, (Grisham \& Misko, 2010) concluded that the existence of HR strategy on four indicators is effective in talent management components namely talent discovery (hiring), talent development, talent evaluation and talent retention. (Cartwright, 2011) concluded that HRM processes can play a role in managing employees' talent. (Mirzaei et al, 2015) indicated that factors such as giving credible and relevant information when hiring, outsourcing based on competence, a clear and perfect job path, effectiveness evaluation system and effective payment system are 
effective on human resources management. Amstrong (translated by Arabi and Izadi, 2015) maintains that HR strategies can significantly influence talent management. Therefore, when an organization gives special privileges to people with high expertise, it applies a variety of attractive incentives to retain skilled and capable human resources, the organization will hire specialized and dedicated human resources for complex positions and jobs. Expertise is a key policy for any organizational post, where it is necessary to spend a great deal of time on consulting with experienced and expert people, hire skilled and experienced people temporarily with high economic incentives specializing in major projects for each department attracts specialized and specialist staff, the organization will hire skilled and experienced HR personnel for each project, pay for recruiting and disseminating the knowledge of skilled people in each field, seek qualified and talented individuals for each project, and to outsource their projects to companies or individuals more, more than anything else they cares about their expertise, is doing outsourcing most of the business as free agent rather than hiring human resources for that procedure and for cutting costs assign outsourced contractors across sectors, then organization managers work hard, to identify talented employes and reward talented and hard-working employees, the organization searchs for and selects top graduates and innovators, in order to identify empowered and talented staff, different staff are interviewed tecnically, competencies and excellence that managers consider are clearly defined and communicated to others, in the organizarion the system and workgroup are created to anticipate potential talents of employees, evaluate each employee's strengths and weaknesses, evaluate employee based their performance on a periodic basis (seasonal or annual), to develop the staff's occupational knowledge, training courses are held within or outside the organization, managers and bosses strive to provide their professional experiences to assistants and staff, helping individuals develop their skills to do better, retain talented and through timely pay, give talented and capable employees special rewards, to compensate talented employees contributions there are allowd to take part in decision-making and administration, and employees' salaries and bonuses are commensurate with their skills, training and education.

\section{CONCLUSION}

Other research results show that knowledge workers have a mediating role in the relationship between HR strategies and talent management. In this regard, (Hughes \& Rog, 2018). studies indicate that the availability of specialized and knowledge staff and specialized training to 
these staff plays a decisive role in human resource management and talent management. (Mirzaei et al, 2015) have concluded that factors such as giving credible and relevant information when hiring, outsourcing, clear and perfect career path, effectiveness evaluation system and effectiveness payment system are effective in human resource maintenance and retention. (Martin, 2009) have concluded that the knowledge-based human resource factor has the greatest impact on talent attraction. Also the results of research by (Grisham \& Misko, 2010) and (Bamberger \& Fiegenbaim, 1996) have shown that $H R$ strategies have an effective role in managing the talent of the organization's employees. Accordingly, it can be said that when employees' knowledge is high in line with the basic concepts and principles in which they are engaged, employees have the ability to reason and solve business problems and have the ability to adapt to technological change, have new and scientific methods of information seeking, be creative and innovative, care about their intellectual and mental development, have rational and defensive thinking, have the ability to plan for their career path and remain as an employee, and the ability to participate in sustainable development and focus on creative thinking and mindsets, to try to avoid rework in the organization, prevent wasting time and money, avoiding wasteful work, have managing and leadership skills, being able to work in multidisciplinary teams, so the organization can perform employee talent management well by employing a free agent strategy for human resources.

\section{PRACTICAL SUGGESTIONS}

As the results of the research show that free agent strategy is the best and most effective HR strategy affecting talent management, the following suggestions are presented for applying free agaent strategy and implemention of this strategy:

- The organization gives special privileges to people who are highly skilled

- Use a variety of encouraging policies to retain skilled and capable human resources.

- The organization hire specialized human resources for complex and specific posts and jobs.

- Employees' expertise for each organizational post is a key policy for the organization.

- If necessary an orginaztion can pays high prices to get advice from people with experience and skill.

- Attract skilled professionals with high economic incentives temporarly.

- To do specialized projects for each section of the department, specialized and specialized staff must be attracted. 
- Provide temporary staff for each project with specialized and experienced personnel.

- Look for talented and gifted people for each project.

- To outsource their projects to companies or individuals outside the organization pay attention to their expertise and skills above all.

- It is better to outsource most of the business procedures rather than hiring staff.

- Periodically outsource to different contractors to reduce costs.

Given that the results of the research showed that knowledge workers play a mediating role in the relationship between HR strategies and talent management, the following suggestions are provided to strengthen the knowledge workers in an organization:

- Employees must strive to enhance their knowledge of the concepts and principles of the occupation in which they are working

- Employees must have the ability to reason and solve job problems and the ability to adapt to technological change.

- Learn new and scientific methods of information search.

- Employees must strive to be creative and innovative, care about their intellectual and mental development, and have rational and defensive thinking

- Employees must be able to plan their career path and remain as an employee.

- Ability to participate in sustainable development and to focus on creative thinking.

- Employees must strive to avoid rework in the organization, avoid wasting time.

- Employees must strive to have leadership and management skills and be able to work in multidisciplinary teams.

\section{REFERENCES}

Tonkejnejad M. \& Davari A. (2009), Human Resources Development with Organizational Sociological Approach, Journal of Human Management Research, Imam Hossein (AS) University, 1 (3): 3: 80-51.

Ebrahimi E. \& Fathi M. (2016). A Framework for Designing Human Resource Strategies. Human Resource Management Research, Imam Hussein University, 8 (3): 31-58.

Lewis R. \& Heckman R. (2006),"Talent Management". Human Resource Management Review, 16 (5): 139-154.

Hughes J. \& Rog E. (2018) Talent management: A strategy for improving employee recruitment, retention and engagement within hospitality organizations ". International Journal of Contemporary Hospitality Management, 20 (7): 743-757. 
Mirzaei H. \& Mojjallal M. \& Beikzadeh J. (2015). Identifying and Prioritizing Factors Affecting Human Resource Conservation in East Azarbaijan Police Force. Najah Human Resources Quarterly, 10 (39): 128-138.

Miller D. (2006)."Strategic Human Resource Management Stores". Journal of Retailing and Services, 36 (2): 99- 109.

Chadwick C. (2005),"The Vital Role of Strategy in Strategic Human Resource Management Education ". Human Resource Management Review, 15 (3): 78-100.

Armstrong M. (2015). Strategic human resource management : a guide to action. Translated by Seyyed Mohammad Erabi and Davood Izadi, Tehran: Office of Cultural Research, 6 (2): 145-156.

Millar P. \& Stevens J. (2012). Managemtn training and national sport organization managers: Examining the impact of training on individual and organizational performances", sport management, 5 (5): 288-303.

Shams Zare M. \& Tahmasebi R. \& Yazdani H. (2017). Assessing the Maturity of Human Resource Management Processes Based on Philips Model. Human Resource Management Research, 10 (1): 75-100.

Soltani I. (2013). The Role of Employee Excellence Model in HRM Development. Tehran: Second National Conference on Performance Management, 11 (4): 269-278.

Karami M. \& Salehi M. (2009). Development of Competency-Based Management (A New Approach in Managing and Developing Managers). Tehran: Ayiizh publication, 13 (1): 196-205.

Li L. \& Zheng Y. \& Zheng F. \& Zhong F. (2009). Cloud computing support for personal knowledge management. International Conference on Information Management, Innovation Management and Industrial Engineering, IEEE Computer Society, 14 (6): 110-124.

Verma S. (2009). Personal knowledge management: A tool to expand knowledge about human cognitive capabilities. IACSIT International Journal of Engineering and Technology, 5 (1): 435- 438.

Bamberger P. \& Meshoulam L. (2014). Human resource Strategy formulation implementation and impact. Translated by Ali Parsaian, Tehran: Office of Cultural Research, 9 (2): 65-74.

Tajeddin M. \& Malaali Tafti M. (2011), Talents Battle, Tadbir Quarterly, 19 (192): 55-64

Michaels E. \& Handfield-Jones H. \& Axelrod B. (2010), The War for Talent, Boston: Harvard Business School Press, 25 (1): 248-260.

Roper O. \& Phillips D. (2009), "A framework for talent management in real estate", Journal of Corporate Real Estate, 11 (1): 7-16.

Bamberger P. \& Philips B. (1991), Organizational Environment versus on HR strategy, Human Resource Management Journal, 30 (1): 417-431.

Bamberger P. \& Mesoulan I. (2005), Human Resource Strategy, London: Sage Publication Inc, 6 (3): 85-94.

Bamberger P. \& Feigenbaum A. (1996), "The Role of Strategic reference Points in Explaining the Nature and Consequences of Human resource Strategy", Academy of Management Review, 21 (4): 926-958. 
Motahari Nejad H. \& Gholi Ghourchian N. \& Jafari P. \& Yaghoubi M. (2012). Purpose of Engineering Education. Journal of Educational Technology Research, 6 (4): 39-50.

Tahmasebi R. \& Gholipour A. \& Javahiri Zadeh A. (2013), Talent Management, Identification and Ranking of Factors Affecting Scientific Talent Recruitment and Retention, Public Management Research, 5 (17): 5-26.

Grisham T. \& Misko Z. (2010), GE Money Americans. In Marshall Goldsmith and Louis Carter. eds): Best Practices in Talent Management: How the World's Leading Corporations Manage, Develop, and Retain Top Talent. John Wiley and sons inc, 9 (4): 148-162.

Cartwright R. (2011), Talent Management, A New Look at Human Capital Development, Translated by: Ali Mohammad Goodarzi, 6 (2): 211-220.

Bamberger P. \& Fiegenbaim A. (1996). The role of strategic reference points in explaining the nature and consequences of human resource strategy. Academy of Management Review, 21 (3): 926-958.

Martin J. (2009). Personal Knowledge Management: the Basic of Corporate and linstitutional knowledgemanagement, Available: www. Spottedcowpress. ca/ knowledge mangement/pdfs/6martinj. Pdfk, 26 (1): 38-47.

McCauley C. \& Wakefield M. (2016) "Talent Management in the 21st Century: Help Your Company Find, Develop, and Keep its Strongest Workers". The Journal for Quality and Participation, 29 (4): 89-114.

Ready D. \& Conger J. (2017), "Make Your Company a talent factory". Harvard Business Review, 85 (6): 68-77.

Schmidt C. \& Henninger M. (2008). Preparing students for the future. Individual knowledge management as a basic skill and requirement for innovative teaching methods. Interactive Computer Aided Learning, ICL, Villach (Österreich), 15 (2): 207-219.

Seetherman A. \& Sooria H. \& Saravanan A. (2012). Intellectual Capital Accounting and Reporting in The Knowledge Economy. Journal of Intellectual Capital), 3 (2): 128-148.

\section{$\underline{\text { ABOUT THE AUTHORS }}$}

\section{Sedigheh Hasani Ahmadiyeh}

Department of Management, Kerman Branch, Islamic Azad University, Kerman, Iran. E-mail: hasaniah200@gmail.com

ORCID: https://orcid.org/0000-0003-1612-4641

\section{Alireza Manzari Tavakoli}

Assistant Professor, Department of Management, Kerman Branch, Islamic Azad University, Kerman, Iran. Email:a.manzari@iauk.ac.ir

ORCID: https://orcid.org/0000-0003-4271-782X

\section{Sanjar Salajegheh}

Assistant Professor, Department of Management, Kerman Branch, Islamic Azad University, Kerman, Iran. Email: s.salajeghe@iauk.ac.ir ORCID: https://orcid.org/0000-0002-3412-6731 
Ayob Sheykhi

Assistant Professor, Department of Statistics, Shahid Bahonar University, kerman, Iran. E-mail: sheikhy.a@uk.ac.ir

ORCID: https://orcid.org/0000-0002-3731-6012

\section{Masoud Pourkiani}

Assistant Professor, Department of Management, Kerman Branch, Islamic Azad University, Kerman, Iran. Email: pourkiani@iauk.ac.ir

ORCID: https://orcid.org/0000-0002-5370-3768

Received on: 12-27-2019

Approved on: 02-19-2020

Published on: 03-18-2020 